\title{
THE DEVELOPMENT OF FARMER AGRARIAN LITERACY IN FACING CHANGES IN TIMES (Sample Framework in Ngawi Regency)
}

\author{
Sugeng Riyanto ${ }^{\left.1^{*}\right)}$, Lilik Wahyuni ${ }^{1}$, Jhauharotul Muchlisyiyah ${ }^{2)}$, Dian Islami Prasetyaningrum ${ }^{1)}$ \\ ${ }^{1}$ Faculty of Agriculture Universitas Brawijaya Malang \\ ${ }^{2}$ Faculty of Agriculture Technology Agriculture Universitas Brawijaya Malang \\ *Corresponding author: sugengriyanto@ub.ac.id \\ To cite this article: \\ Riyanto, S., Wahyuni, L., Muchlisyiyah, J., \& Prasetyaningrum, D. (2021). The Development of Farmer Agrarian \\ Literacy in Facing Changes in Times (Sample Framework in Ngawi Regency). International Journal of Agricultural \\ Social Economics and Rural Development (ljaserd), 1(2), 73 - 79. \\ doi:http://dx.doi.org/10.37149/ijaserd.v1i2.20911
}

Received: October 01, 2021; Accepted: December 12, 2021; Published: December 13, 2021

\begin{abstract}
Increased infrastructure development has significantly impacted world agriculture, generally in Indonesia and particularly in Ngawi Regency. Due to the narrowing of agricultural land is an unavoidable necessity. It can be seen in the annual loss of agricultural land due to the eroded flow of development, which will doubt harm agricultural production. Because the agricultural land is decreasing, achieving food self-sufficiency in the world in the coming years will be difficult. The fact is the cause of the narrowness of agricultural land for infrastructure development. In addressing the issues mentioned above, research into the knowledge/literacy of farmers in the Ngawi Regency is required; specifically, developing farmer knowledge will enable farmers to continue farming. According to the research's findings: farmers have a deep understanding of agriculture; they mostly learn from their parents, the Internet, and neighbors; farmers learn about pest and disease cultivation and marketing aspects from the Internet.
\end{abstract}

Keywords: development; farmer literacy; Ngawi

\section{INTRODUCTION}

Increased infrastructure development significantly impacts world agriculture (Bacior \& Prus, 2018), including Indonesia generally and Kabupateng Ngawi particularly. The narrowing of agricultural land is kinetic that cannot be denied. It can be seen from agricultural land, which is increasingly reduced every year because it is eroded by the flow of development (Putri, 2016). It certainly can harm agricultural production. Because agricultural land is increasingly reduced, the possibility of the next few years for food self-sufficiency in the world will be challenging to fulfill (Simelton, 2011).

The narrowing of agricultural land is a broad decline and land volume, making it less suitable for large-scale agrarian needs (Utami et al., 2019). Agricultural land is reduced by 200,000 ha/year. As said by the BPS (2018), rice fields' raw land area continues to decline. In 2018, the land area was only 7.1 million hectares. This number is considered decreasing compared to 2017 , which was still 7.75 million hectares (Indonesia, 2020). The decline in agricultural land impacts the many people looking for jobs and residences in the city as Bappenas said that based on differences in the rate of population growth of urban and rural areas (Urban-Rural Growth Difference / URGD), the urban population continues to increase. Between 2015-2020 is predicted to increase urbanization from $53.3 \%$ to $56.7 \%$. In 2035 it was projected to be $66.6 \%$. The urbanization rate of Indonesia is the highest in Asia (Hayyu, 2020).

Various attempts have been made to halt agricultural land conversion. As stated by the Head of BPS that one way to take advantage of land conversion is to provide incentives to farmers who maintain their agricultural land (CNN Indonesia, 2020). However, this method cannot solve the problem. Urbanization and professional change continue yearly (Swastika, 2014), (Astuti et al., 2020). Efforts to overcome the difficulties of the profession of farmers tend to be underestimated by the community (Harsono, 2009). The number of farmers decreased, and other occupations increased every year. Non-agricultural professions such as trade and industrial labor become a preference for 
the urban communities (Swastika, 2014), (Astuti et al., 2020).

In overcoming the problems above, it is necessary to study farmers' agricultural knowledge/literacy in Ngawi Regency. Farmer knowledge is directly proportional to the increase in agriculture human resources. The increasing human resources in the agricultural sector are expected to increase farmers' economy in Ngawi Regency and the country obtained from the agricultural industry. In addition, it also has an impact on the welfare of farmers. Suppose the interest of farmers increases, career shifting to other sectors may be avoided. The reduced career shifting will maintain the agricultural land to be sustainable.

\section{MATERIALS AND METHODS}

This research used a qualitative approach that extracting data to understand the social phenomena based on a comprehensive (Holistic) analysis formed by words and obtained from a natural situation. Yin (2002) The research was conducted from May to November 2021. The number of respondents in this study was 54 people and selected respondents using the snowball sampling method. The data analysis was conducted using the descriptive analysis method to observe the phenomenon of the literacy development of farmers in the Ngawi Regency.

\section{RESEARCH RESULTS AND DISCUSSION}

\section{The Education Level of Respondents}

Based on the interview, most of the farmers in Ngawi Regency who were our respondents had a high level of education, namely high school. The high level of education is expected to become capital for agricultural development in Ngawi Regency. It will be much easier for the government to provide directions (Movahedi \& Nagel, 2012) and introduce technology to farmers. However, this information should be re-checked against local government data to ensure that most farmers have completed high school.

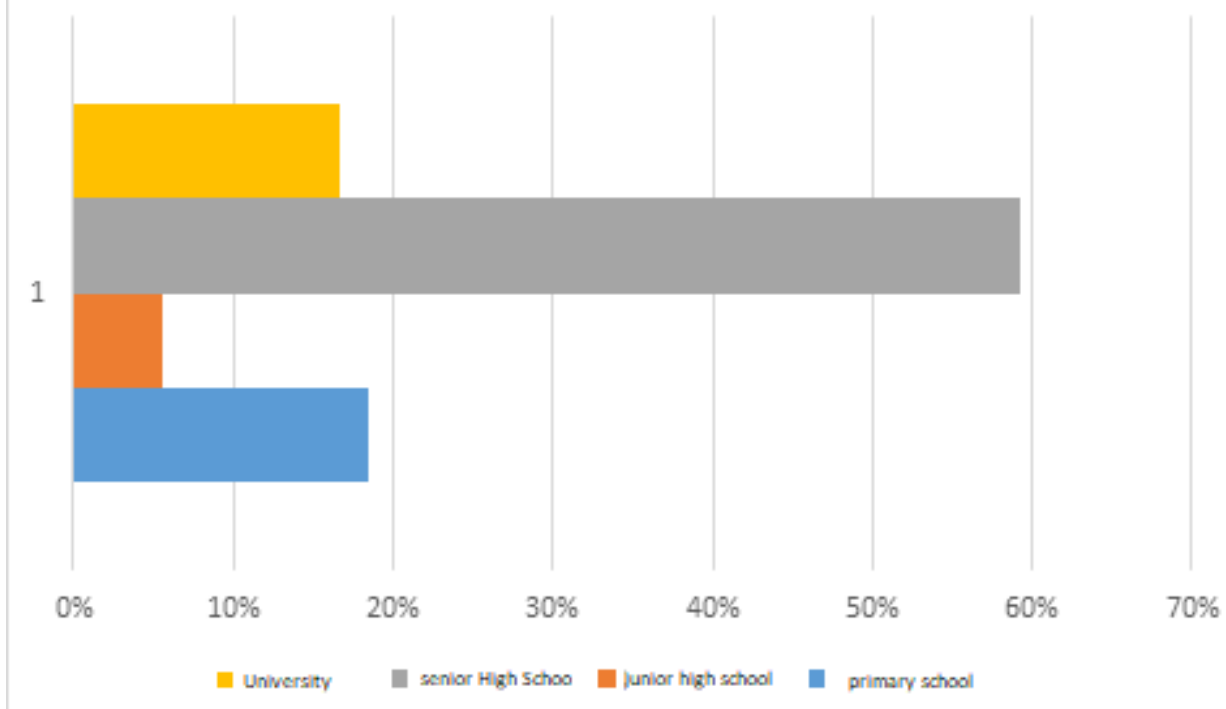

Figure 1. The education level of respondents.

\section{The Ability of Farmers to Read and Write}

Based on the findings from both offline and online interviews, most or all of the farmers could read, so the average farmer in Ngawi Regency is literate. So that government will find it easier to conduct counseling and provide information related to developed technology. The reading ability possessed by farmers should utilize various channels in extension activities, both audio and visual. It can also be in simple writings in pamphlets/brochures that are understandable for farmers. With this reading ability, the extensions in simple writing or pamphlets/brochures are effective during group meetings (Pertiwi \& Saleh, 2010). For instance, providing pamphlets/brochures for instructions on using pesticides, safe use pesticides, post-harvest processing, simple technology in agricultural land management, technology for handling pests and diseases of mice, and technology in handling natural enemies such as snakes and snakes, birds of prey, also known as owls. 
The government can use simple technology in carrying out extension activities by using audio and visual media (Simamora, 20119). Local governments create specific YouTube channels that their extension workers prepare and are expected to develop content related to agriculture. For example, pest and disease management content can be directly disseminated to farmers via their Whatsapp groups or played during the activity, followed by some explanations (Eksanika \& Riyanto, 2017) that the Internet can provide a wealth of information. This method will run very effectively, and farmers will quickly understand the materials. Furthermore, farmers can learn anytime, anywhere by clicking the provided link.
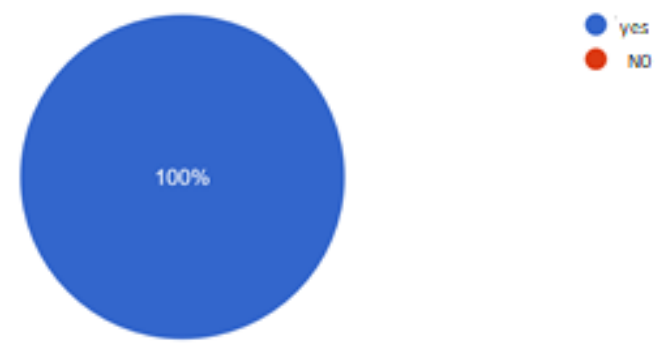

Figure 2. Chart scattering ability to read and write farmers

\section{Simple Calculation Ability for Farming Calculations}

They are related to the ability/knowledge of farmers with their farming calculations (Phahlevi, 2013). The researchers said that the farmers have already understood that they experienced loss. According to the data, $64 \%$ of respondents know they lose money when planting certain commodities in certain seasons; for example, farmers will experience a loss due to the costs and yields of BEP results. Farmers continue to do farming because they can still make a profit. For example, grass and straw can be used for their livestock or sometimes fill up their spare time. However, some farmers don't understand the calculation. About $35 \%$ of them say that the essential thing is planting and that they may be profitable but can't calculate it mathematically. They don't keep track of how much energy they use daily. The farmer calculates the amount of capital he sells, but if he does, he loses (Panurat et al., 2014).

Even though the loss remained, there was no other job, or they were old enough to continue farming for daily activities. The data from this research is sufficient about the loss of farming is still global, so it is necessary to do a more detailed analysis on the farming calculation. Is it true that their farming business is profitable? Is it true that their farming business is losing? With the HPP calculation, the researcher only looks at it from the point of view of knowing whether their farming business is profitable or losing (Sugianto \& Salfarini, 2020).

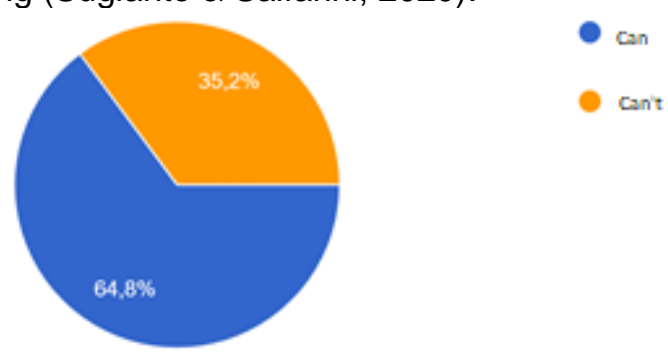

Figure 3. Simple calculation ability for farming calculations

\section{Knowledge of Agricultural Local Terms}

The knowledge of farmers related to local agricultural terms is excellent. They have already known many terms used in managing the farm (Tandur, Matun, Bero, Maring, Rendeng, Mongso). They use those terms every day so that they master the terms well. This recent research recommends keeping the local terms as the wealth of agriculture. If those terms disappear, it may be a big problem because those terms have the characteristics and knowledge of the farmers (Mulyoutami et al., 2004). It will become a problem if local agricultural literacy or understanding of local knowledge is lost. Farmers have much local knowledge, which is fading due to external entry technology, which removes farmers' local knowledge. Local knowledge usually directs environmentally friendly agriculture than the Sindang community in handling insect pests by burning the branches (Ansiska et al., 2020). It is an example of local knowledge that must be maintained to support local literacy. The agricultural efficiency will emerge when the efficiency of the question 
arises if we discuss self-sufficiency and the welfare of farmers. Local knowledge will be one of the drivers of increasing farmers' interest and independence because the production costs do not have to be purchased. However, farmers must now buy all agricultural production costs (Nugraheni, 2015)
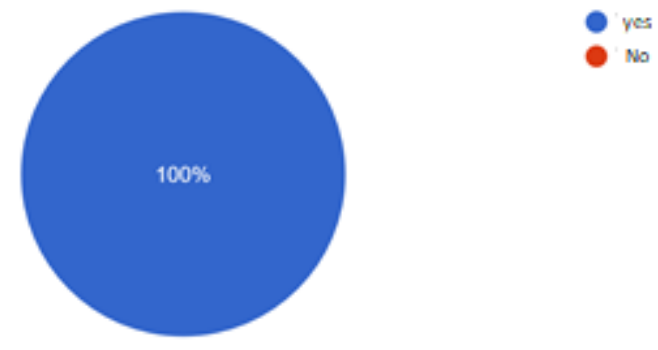

Figure 4. Knowledge of local agricultural terms

\section{Internet operation}

The internet operation is related to the knowledge of farmers in modern times. Farmers have begun to interact with the virtual world/internet. Many of the farmers have started using Facebook, YouTube, etc. Farmers, whether young or half old, have used the Internet. The Internet will then be very familiar to the younger farmers (Eksanika \& Riyanto, 2017). From the data, I collected farmers who already understood the Internet. Approximately $87 \%$ and $13 \%$ stated that they had not known the Internet. They are aware that most farmers' access to the Internet is limited to WhatsApp and that young farmers are already familiar with Facebook and YouTube. Farmers will learn about shipments from Facebook friends through the media. However, there is no denying that farmers have yet to contact the Internet (Delima, 2016). Farmers who do not have access to the Internet are typically elderly or unable to afford these services.

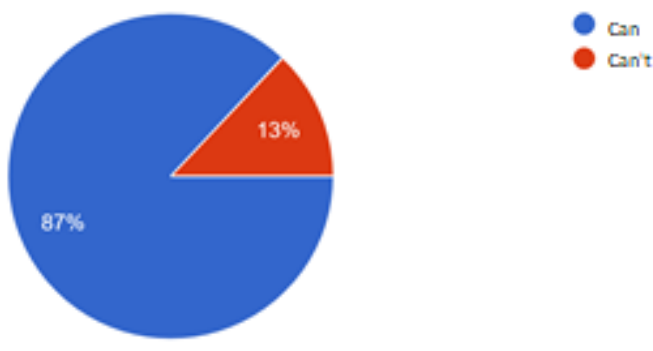

Figure 5. Internet operation knowledge

\section{Internet Usage}

According to the data, most farmers $(46.3 \%)$ used the Internet to socialize in line with the previous discussion of the use of WhatsApp and Facebook (Prabowo \& Arofah, 2017). Additionally, the respondents said they could learn certain things and recognize the agricultural market from the socialization activities. Respondents specifically explained that farmers used the Internet for farming activities $(22.2 \%)$. It was encouraging that $9.3 \%$ of the farmers also made sales online. Using the Internet in sales has not yet reached $10 \%$, but this is a forerunner to the future use of the Internet for farmers in Ngawi Regency as a medium of agricultural product marketing. Internet-based marketing to introduce agricultural products outside the Ngawi Regency and abroad. The Internet will make it easier to use and prevent intermediaries from playing prices to be more prosperous (Prayoga, 2015).
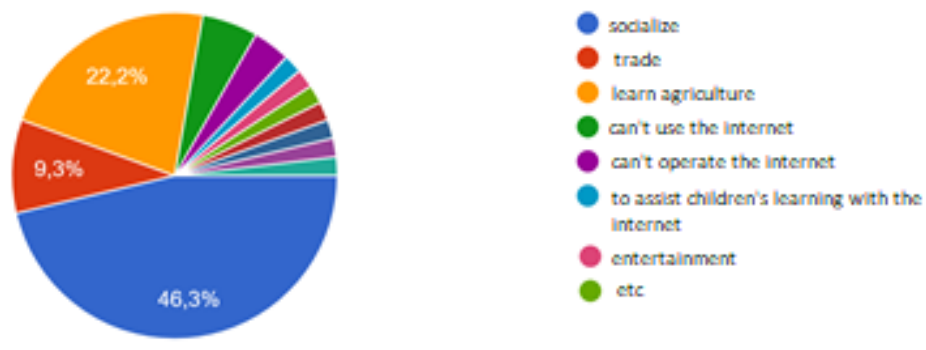

Figure 6. Internet usage for farmers 


\section{How farmers have been studying agriculture}

In this section, the farmer said they studied agriculture from anywhere and generally from their parents (74.1\%). They follow their parents working in the fields (Anwarudin et al., 2020). Young farmers also experienced the same by learning directly from their parents. Secondly, they studied agriculture from the extension agents (18.5\%), including the extension activities, the plot demonstration, regular meetings, and farm tours. Farmers expect the intensity of learning from extension workers will also be increasingly more significant in the future. They hope their agricultural products will increase along with their knowledge. Next is learning from the Internet, friends, and neighbors.

Interestingly, the Internet has started to be a learning medium for Ngawi Regency farmers. The percentage will increase when farmers are more familiar with the Internet in the future. Farmers who have begun to open and learn from the Internet will open up their minds on applying new technology to improve their agricultural business by using all learning media available on the Internet, both domestically and internationally (Mulyandari, 2011). If the infrastructures that support farmers are open in the future, they will learn faster and be more enthusiastic about the development of agricultural businesses. Then, a campaign promoting local wealth must preserve the regional characteristics and wealth passed down from generation to generation by their parents.

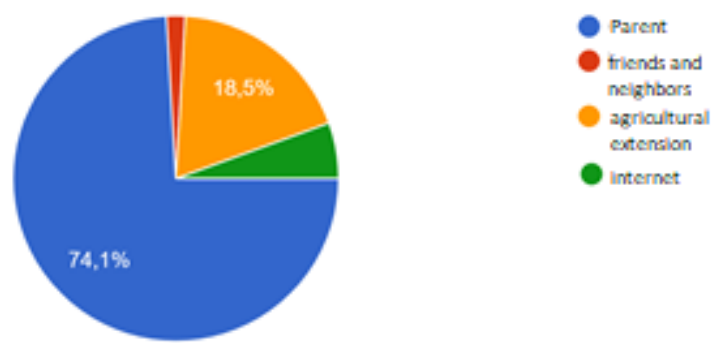

Figure 7. Farmers Learning Resources

\section{Knowledge learned by the Farmers from the Internet}

This research sharpens the questions to farmers who use the Internet by asking what knowledge they learned through the Internet. $74 \%$ of respondents stated that they specifically learned about cultivation, $18 \%$ knew about controlling pests. They also learned how to make fertilizers while learning about agricultural products marketing. Similar to the research results from Prawiranegara (2016), 32\% of farmers managed information as a benchmark in a farmer's business. In short, farmers are still struggling with production but lack knowledge, and only a few are learning about marketing. It is due to the lack of marketing skills learned directly from the Internet (Apriliani et al., 2021). The Internet is expected to create a new market for farmers by connecting farmers and buyers (Aprilliyanti \& Riyanto, 2020).
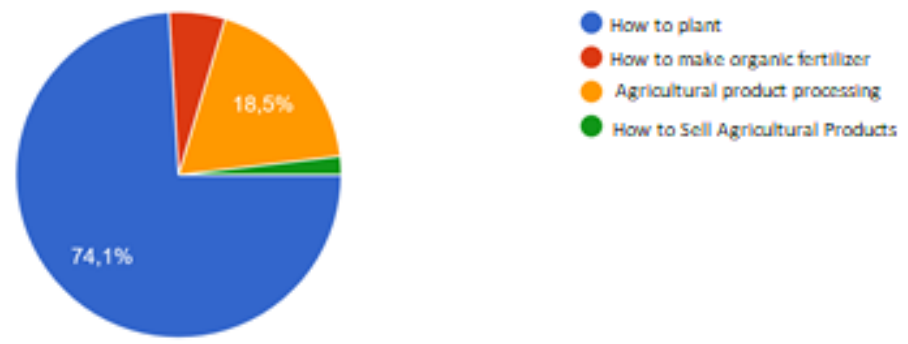

Figure 8. Knowledge learned from the Internet

\section{CONCLUSION}

This study provides three conclusions. First, farmers already had excellent agricultural literacy. The reading and writing ability proved by $100 \%$ of farmers can read and have simple calculation knowledge in agricultural products. $65 \%$ of farmers can calculate $35 \%$ cannot count. Next, the local knowledge that farmers have. Most farmers learn from parents $(74.1 \%)$, extension activities $(18.5 \%)$, the Internet, and friends. The third conclusion is that they have started to learn about agriculture by using the Internet. The knowledge gained from the Internet includes cultivation (74\%), post-harvest $(18 \%)$, and also marketing $(9,3 \%)$. The majority of them are still having difficulty with 
cultivation. So that, in the future, it needs to be developed to help the farmers learn and gain much information about marketing agricultural products over the Internet.

\section{REFERENCES}

Ansiska, P., Windari, E. H., \& Sari, M. I. (2020). Rekomendasi Pembangunan Perkebunan Kopi Masyarakat Sindang Melalui Kajian Ethnoagriculture. Agriculture, 1(2).

Anwarudin, O., Sumardjo, S., Satria, A., \& Fatchiya, A. (2020). Peranan penyuluh pertanian dalam mendukung keberlanjutan agribisnis petani muda di Kabupaten Majalengka. Jurnal Agribisnis Terpadu, 13(1), 17-36.

Apriliani, I. M., Rizal, A., \& Suryana, A. A. H. (2021). Pembekalan Teknik Penjualan Melalui Media Online untuk Hasil Olahan Komoditi Pertanian dan Perikanan pada Aliansi Perempuan Peduli Lingkungan Sumedang (APPeLS) Desa Cikeruh, Kecamatan Jatinangor, Kabupaten Sumedang. Farmers: Journal of Community Services, 2(2), 51-56.

Aprilliyanti, A., \& Riyanto, S. (2020). Analisis Peran Media Sosial dalam Pemasaran Sayur di Tingkat Petani Desa Dalisodo Kecamatan Wagir Kabupaten Malang. Jurnal Indonesia Sosial Sains, 1(3), 165-171.

Astuti, W., Manan, A., \& Ma'ruf, A. (2020). Economic Life of Coastal Communities: A Study of Meleura Beach Tourism Objects. Journal La Lifesci, 1(2), 17-22.

Bacior, S., \& Prus, B. (2018). Infrastructure development and its influence on agricultural land and regional sustainable development. Ecological Informatics, 44, 82-93.

BPS. (2018). Statistik Indonesia Tahun 2018. Badan Pusat Statistik.

Delima, R. (2016). Analisis kondisi dan kesiapan masyarakat tani di Daerah Istimewa Yogyakarta untuk memanfaatkan TIK di bidang pertanian. Konferensi Nasional Teknologi Informasi dan Komunikasi, 118-126.

Eksanika, P., \& Riyanto, S. (2017). Pemanfaatan Internet oleh Penyuluh Pertanian. Jurnal Sains Komunikasi dan Pengembangan Masyarakat. JSKPM, 1(1), 65-80.

Harsono, D. (2009). Pembangunan Pertanian yang Berpihak pada Petani. Informasi, 35(2).

Hayyu, A. M. N. F. (2020). Mengelola Urbanisasi untuk Pertumbuhan Ekonomi.

Indonesia, C. (2020). BPS sebut lahan pertanian kian menurun.

Movahedi, R., \& Nagel, U. J. (2012). Identifying required competencies for the agricultural extension and education undergraduates.

Mulyandari, R. S. (2011). Perilaku petani sayuran dalam memanfaatkan teknologi informasi. Jurnal Perpustakaan Pertanian, 20(1), 22-34.

Mulyoutami, E., Stefanus, E., Schalenbourg, W., \& Rahayu, S. (2004). Pengetahuan lokal petani dan inovasi ekologi dalam konservasi dan pengolahan tanah pada pertanian berbasis kopi di Sumberjaya, Lampung Barat. Agrivita, 26(1), 98-107.

Nugraheni, S. I. W. I. (2015). Produksi Padi Berkelanjutan. Kompas Daily Newspaper, 6.

Panurat, S. M., Porajouw, O., Loho, A. F., \& Rumagit, G. A. J. (2014). Faktor-faktor yang mempengaruhi minat petani berusahatani padi di Desa Sendangan Kecamatan Kakas Kabupaten Minahasa. In Cocos, 4(5).

Pertiwi, P. R., \& Saleh, A. (2010). Persepsi petani tentang saluran komunikasi usahatani padi. Jurnal Komunikasi Pembangunan. 8(2).

Phahlevi, R. (2013). Faktor-faktor yang mempengaruhi pendapatan petani padi sawah di Kota Padang Panjang. Jurnal Kajian Ekonomi Dan Pembangunan, 1(02).

Prabowo, A., \& Arofah, K. (2017). Media Sosial Instagram Sebagai Sarana Sosialisasi Kebijakan Penyiaran Digital. Jurnal Aspikom, 3(2), 256-269.

Prawiranegara, D. (2016). Pengaruh kualitas informasi berbasis cyber terhadap kapabilitas petani sayuran mengelola inovasi di Jawa Barat. Sosiohumaniora, 18(2), 166-172.

Prayoga, K. (2015). Aplikasi Digital Pertanian: Geliat Pemberdayaan Petani di Era Virtual. Sumber. Https://Www.Academia.Edu/32400957/Aplikasi_Digital_Pertanian_Geliat_Pemberdayaan_Pe tani_Di_Era_Virtual

Putri, Z. R. (2016). Analisis penyebab alih fungsi lahan pertanian ke lahan non pertanian kabupaten/kota di Provinsi Jawa Tengah 2003-2013. Eko-Regional: Jurnal Pembangunan Ekonomi Wilayah, 10(1).

Simamora, R. H. (20119). Pengaruh Penyuluhan Identifikasi Pasien dengan Menggunakan Media Audiovisual terhadap Pengetahuan Pasien Rawat Inap. Jurnal Keperawatan Silampari, 3(1), 342-351.

Simelton, E. (2011). Food self-sufficiency and natural hazards in China. Food Security, 3(1), 35-52. 
Sugianto, H. A. T., \& Salfarini, E. M. (2020). Kapital Spiritual Di Balik Kemampuan Bertahan Hidup Para Petani Ladang Miskin. Sosio Informa, 6(3), 280-291.

Swastika, D. K. S. (2014). Reformasi paradigma urbanisasi: strategi percepatan pengentasan kemiskinan di perdesaan. . Badan Penelitian dan Pengembangan Kementrian Pertanian Indonesia.

Utami, A. F., Ayu, C. A. C., \& Anwar, A. (2019). Dampak Konversi Lahan Pertanian Terhadap Pola Produksi Dan Pola Konsumsi Rumahtangga Petani Di Kota Mataram. Jurnal Agrimason, 20(1), 10-18.

Yin, R. K. (2002). Case study research: Design and methods. CA: SAGE Publications. 